\title{
Morphological Characteristics and Phylogenetic Trends of Trematode Cercariae in Freshwater Snails from Nakhon Nayok Province, Thailand
}

\author{
Thapana Chontananarth ${ }^{1,2, *}$, Thanawan Tejangkura ${ }^{1,2}$, Napat Wetchasart ${ }^{1}$, Cherdchay Chimburut ${ }^{1}$ \\ ${ }^{1}$ Parasitology Research Laboratory, Department of Biology, Faculty of Science, ${ }^{2}$ Center of Excellence in Animal, Plant and Parasitic Biotechnology, \\ Srinakharinwirot University, Bangkok 10110, Thailand
}

\begin{abstract}
The prevalence of cercarial infection in freshwater snails and their evolutionary trends were studied in Nakhon Nayok province, Thailand. A total of 2,869 individual snails were examined for parasitic infections. The results showed that 12 snail species were found to host larval stages of trematodes with an overall prevalence of $4.7 \%$. The infected specimens included 7 types at the cercarial stage; cercariae, megalurous cercariae, echinostome cercariae, furcocercous cercariae, parapleurolophocercous cercariae, virgulate cercariae, and xiphidiocercariae. Regarding molecular identification, ITS2 sequence data of each larval trematode were analyzed, and a dendrogram was constructed using the neighbor-joining method with 10,000 replicates. The dendrogram was separated into 6 clades (order/family), including Echinostomatida/Echinostomatidae, Echinostomatida/Philophthalmidae, Opisthorchiida/Heterophyidae, Plagiorchiida/Prosthogonimidae, Plagiorchiida/Lecithodendriidae, and Strigeatida/Cyathocotylidae. These findings were used to confirm morphological characteristics and evolutionary trends of each type of cercariae discovered in Nakhon Nayok province. Furthermore, this investigation confirmed that the ITS2 data of cercariae could be used to study on phylogenetic relationships or to determine classification of this species at order and/or family level when possible.
\end{abstract}

Key words: prevalence, phylogenetic relationship, trematode, cercaria, snail, Nakhon Nayok province, ITS2, Thailand

\section{INTRODUCTION}

Snail-transmitted diseases have been acknowledged as an element of the integral stage of several parasitic diseases that are transmittable to humans. This is due to the fact that many snail species act as intermediate hosts within the trematode transmission cycle [1]. Generally, many species of freshwater snails belong to a class of gastropods that are involved in the process of infection that takes place in definitive hosts and which can cause severe debilitating pathogenicity in many of those hosts.

Many different types of cercariae have been identified, and in some cases distinct types can be assigned to families, superfamilies, or genera. For example, pleurolophocercous cercariae have been identified as trematodes of the families Heterophyidae, Opisthorchiidae, and Cryptogonimidae [2,3], while echi-

- Received 4 September 2016, revised 1 December 2016, accepted 24 December 2016.

*Corresponding author (thapana@g.swu.ac.th)

(c) 2017, Korean Society for Parasitology and Tropical Medicine

This is an Open Access article distributed under the terms of the Creative Commons Attribution Non-Commercial License (http://creativecommons.org/licenses/by-nc/4.0) which permits unrestricted non-commercial use, distribution, and reproduction in any

medium, provided the original work is properly cited. nostome cercariae have been identified as Echinostomatidae [4] and amphistome cercariae as Paramphistomatidae [5]. Several studies have previously reported the incidence of trematode infections in various snail species in Thailand. For instance, Wongsawad and Kumchoo [6] reported on the recovery of Transversotrema patialensis cercariae in thiarid snails, Thiara scabra [6]. Ngern-klun et al. [7] identified 4 types of cercariae, including lophocercous cercariae, monostome cercariae, pleurolophocercous cercariae, and virgulate cercariae in Bithynia funiculata with an overall prevalence of $9.6 \%$. Moreover, Dechruksa et al. [8] reported 2 types of cercariae (parapleurolophocercous cercariae and xiphidiocercariae) in thiarid snails from the Khek River in Phitsanulok province, Thailand with an overall prevalence of $0.9 \%$. A previous study reported on the epidemiology of trematodes in freshwater animals (fish, snail, crab, and shrimp) in 5 provinces specifically involving Chiang Mai, Chiang Rai, Phayao, Lampang, and Phrae provinces; furcocercous and pleurolophocercous cercariae were found in Melanoides tuberculata snails exclusively in Phrae province [9]. Recently, Krailas et al. [10] investigated cercarial infections in freshwater snails acquired from Khao Yai National Park, Thailand and reported 3 species, namely, Apatemon 
gracilis, Mesostephanus appendiculatus, and Loxogenoides bicolor. Finally, Anucherngchai et al. [11] reported 9 types of cercarial infections, including cercariae, echinostome cercariae, furcocercous cercariae, megarulous cercariae, monostome cercariae, pleurolophocercous cercariae, parapleurolophocercous cercariae, virgulate cercariae, and xiphidiocercariae in freshwater snails from 10 provinces of the Chao-Phraya Basin with an overall prevalence of $5.9 \%$.

The conventional methods used to examine cercarial infections in snails are typically performed by exposing the snails to light (shedding) and/or by dissection (crushing), which would serve to enable the researcher to clearly observe the cercariae. However, it can be difficult to identify the infection at the species level using these methods, since the larval morphology is similar to each other [12]. Consequently, molecular biological approaches have been used for the purpose of accurate identification at larval stages $[2,13,14]$. Of particular interest, the internal transcribed spacer 2 (ITS2) was used for the identification of cercariae, metacercariae, and adult stage in both intermediate and/or definitive hosts [15-17]. Moreover, the sequence data of ITS2 region was used to establish molecular markers for the purpose to distinguish and identify each organism at the species and population levels [18]. Therefore, ITS2 region has proven to be beneficial when used as a tool to efficiently acquire accurate results as a time-saving identifica- tion technique. The examples of studied parasites included heterophyids [17,19,20], Fasciola hepatica [15,21], Echinostomatidae [22], and Paramphistomatidae [23].

The purpose of this study was to investigate the prevalence of cercarial infection in freshwater snails acquired from Nakhon Nayok province and to reestablish a phylogenetic tree demonstrating the evolutionary trends of trematodes using definite analytical procedures based on a PCR technique focusing on ITS2 region. The results of this study would serve as the first step for providing novel information on trematode infections and could be used for development of effective control measures that could be applied in Nakhon Nayok province, Thailand.

\section{MATERIALS AND METHODS}

\section{Surveyed areas and collection of snails}

Total 2,869 snail specimens were collected from 46 study sites located in 4 districts (Banna, Ongkharak, Muang, and Pak Phli) of Nakhon Nayok province in central Thailand. These 4 districts were home to a variety of activities that can influence water bodies and are associated with both animals and humans, such as irrigation canals, fishing communities along the riverbanks, water consumption points, paddy fields, as well as others (Fig 1). The snail specimens were identified according

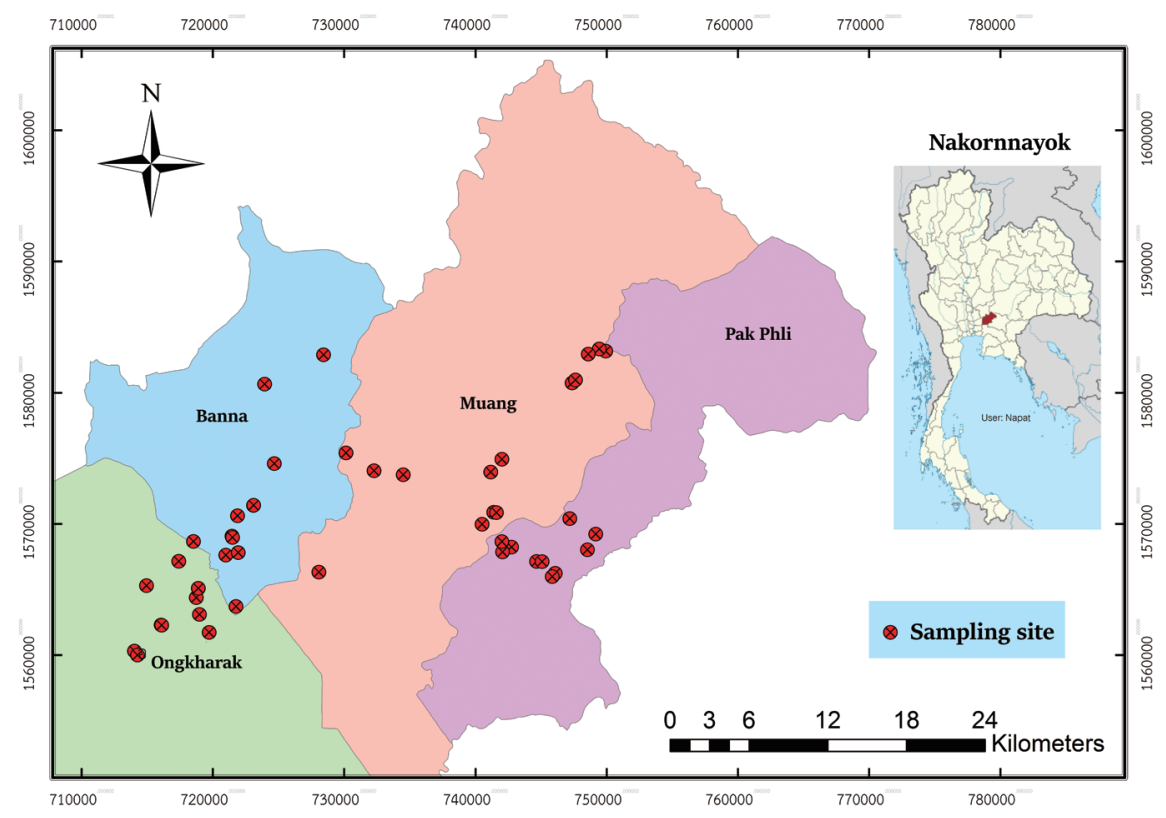

Fig. 1. Map of the 64 sampling sites that were investigated in this study. 
to the method of Brandt [24] who provided a taxonomic key for the identification of non-marine aquatic snails of Thailand.

\section{Examination of cercariae from snails}

Collected snails were rinsed in chlorine-free water to remove sediment and plant material. Each individual snail was examined for cercarial infection using the crushing method under a light microscope [19]. The cercarial samples were vitally stained with $0.5 \%$ neutral red and identified according to the morphology as has been described in previous reports [25-27]. In addition, the cercarial specimens were stained with Delafield's hematoxylin or aceto-orcein. They were then dehydrated in an ethyl alcohol series, cleared with xylene, and mounted in permount. Illustrations were made using a camera lucida to record information on the morphological characteristics. The cercariae were identified at the family level, and in some cases identification at the genus was possible.

\section{Molecular identification}

Each type of cercaria was fixed with 70\% ethanol and further processed for DNA extraction using the commercial GF-1 tissue DNA extraction kit (Vivantis, Shah Alam, Malaysia) according to the manufacturer's instructions. A pair of primers that have been applied by Barber et al. [28] was used for the amplification of ITS2 fragments. It consisted of ITS3 (5'-gCA TCg ATg AAg AAC gCA gC-3'), and the reverse primer was ITS4 (5' TCC
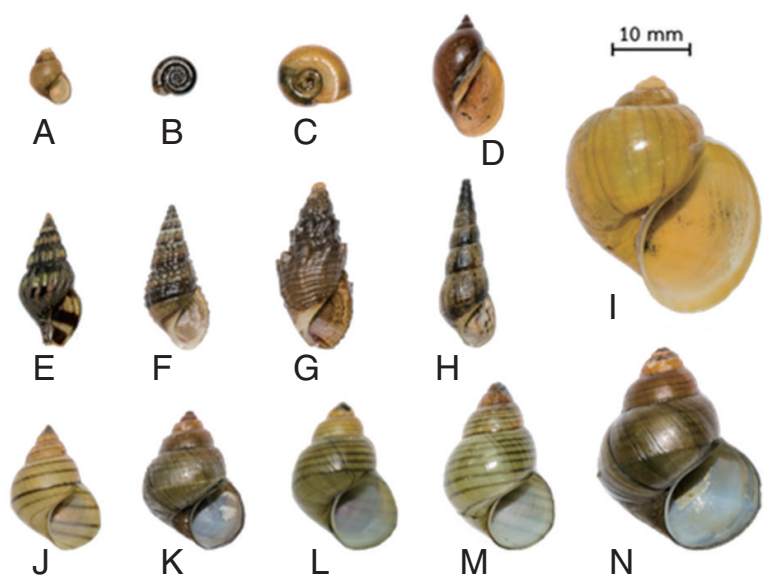

Fig. 2. The shells of 14 snail taxa collected in this study. (A) Bithynia siamensis. (B) Gyraulus sp. (C) Indoplanorbis exustus. (D) Lymnaea auricularia. (E) Clea helena. (F) Tarebia granifera. (G) Thiara scabra. (H) Melanoides tuberculata. (I) Pomacea sp. (J) Filopaludina doliaris. (K) Sinotaia sp. (L) Filopaludina speciose. (M) Filopaludina martensi. (N) Filopaludina polygramma.
TCC gCT TAT TgA TAT gC-3'). The PCR conditions involved pre-denaturing at $94^{\circ} \mathrm{C}$ for $4 \mathrm{~min}$ or denaturing at $94^{\circ} \mathrm{C}$ for 1 min. The annealing time was set at 30 secs at $50^{\circ} \mathrm{C}$, extension was performed at $72^{\circ} \mathrm{C}$ for $45 \mathrm{~min}$, and final extension was performed at $72^{\circ} \mathrm{C}$ for $7 \mathrm{~min}$. A $50-\mu l$ of each PCR reaction was

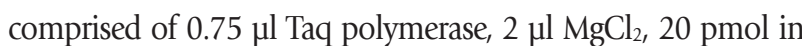
$1.25 \mu \mathrm{l}$ of each primer, $5 \mu \mathrm{l}$ buffer, $1 \mu \mathrm{dNTP}$, and $2.5 \mu \mathrm{l}$ of the DNA template. The amplicons were separated by gel electrophoresis using 1.4\% agarose gel at a voltage of 90 amps for 45 min. After that, the sequence data of each DNA sample were confirmed according to the PCR target using the standard nucleotide Basic Local Alignment Search Tool (BLAST) with megablast acquired from the NCBI database. Consequently, the sequence data were aligned, and the phylogenetic tree was constructed with the Mega $6^{\circledR}$ program using the neighbor-joining tree method with 10,000 bootstrap tests.

\section{RESULTS}

A total of 2,869 snail specimens were collected from Nakhon Nayok province, Thailand. They were classified into 7 families, 11 genera, and 14 species; the Bithyniidae (Bithynia siamensis), Viviparidae (Filopaludina doliaris, F. martensi martensi, F. polygramma, F. speciose, Sinotia sp.), Buccinidae (Clea helena), Planorbidae (Gyraulus sp., Indoplanorbis exustus), Lymnaeidae (Lymnaea auricularia), Thiaridae (M. tuberculata, Tarebia granifera, T. scabra), and Ampullariidae (Pomacea sp.) (Fig. 2). M. tuberculata (Thiaridae) was identified as the most suscepti-

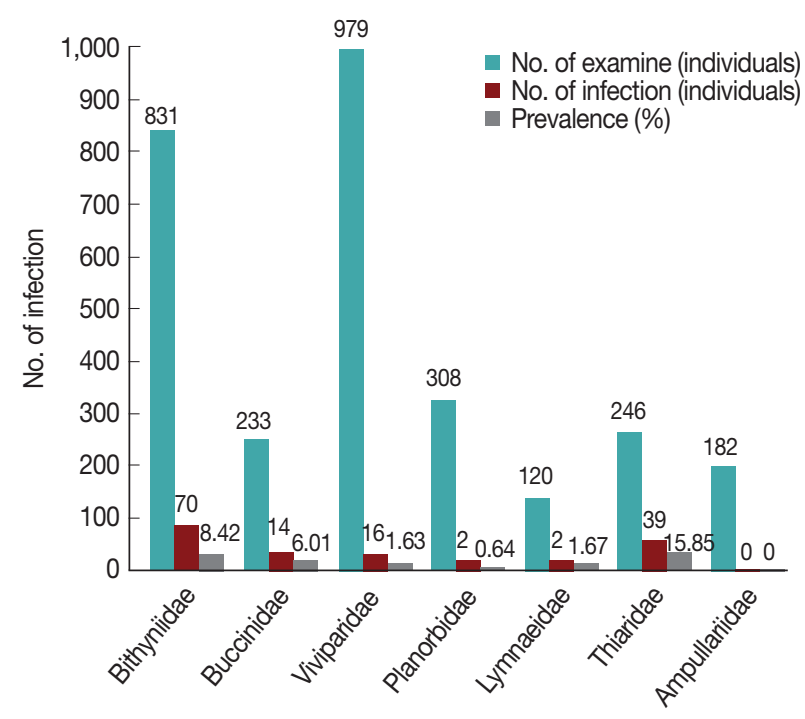

Fig. 3. The prevalence of cercarial infections in each snail family. 
ble snail species for cercarial infections over other snail families, with a prevalence of $15.9 \%$. The prevalence of cercarial infections of the other snail families was as follows: Bithyniidae (8.4\%), Buccinidae (6.0\%), Lymnaeidae (1.7\%), Viviparidae (1.6\%), and Planorbidae (0.64\%) (Fig. 3).
At this location, a total of 7 morphological types of cercariae were found, including cercariae, megalurous cercariae, echinostome cercariae, furcocercous cercariae, parapleurolophocercous cercariae, virgulate cercariae, and xiphidiocercariae (Fig. 4). Regarding the cercarial infections in the snails, it was indi-

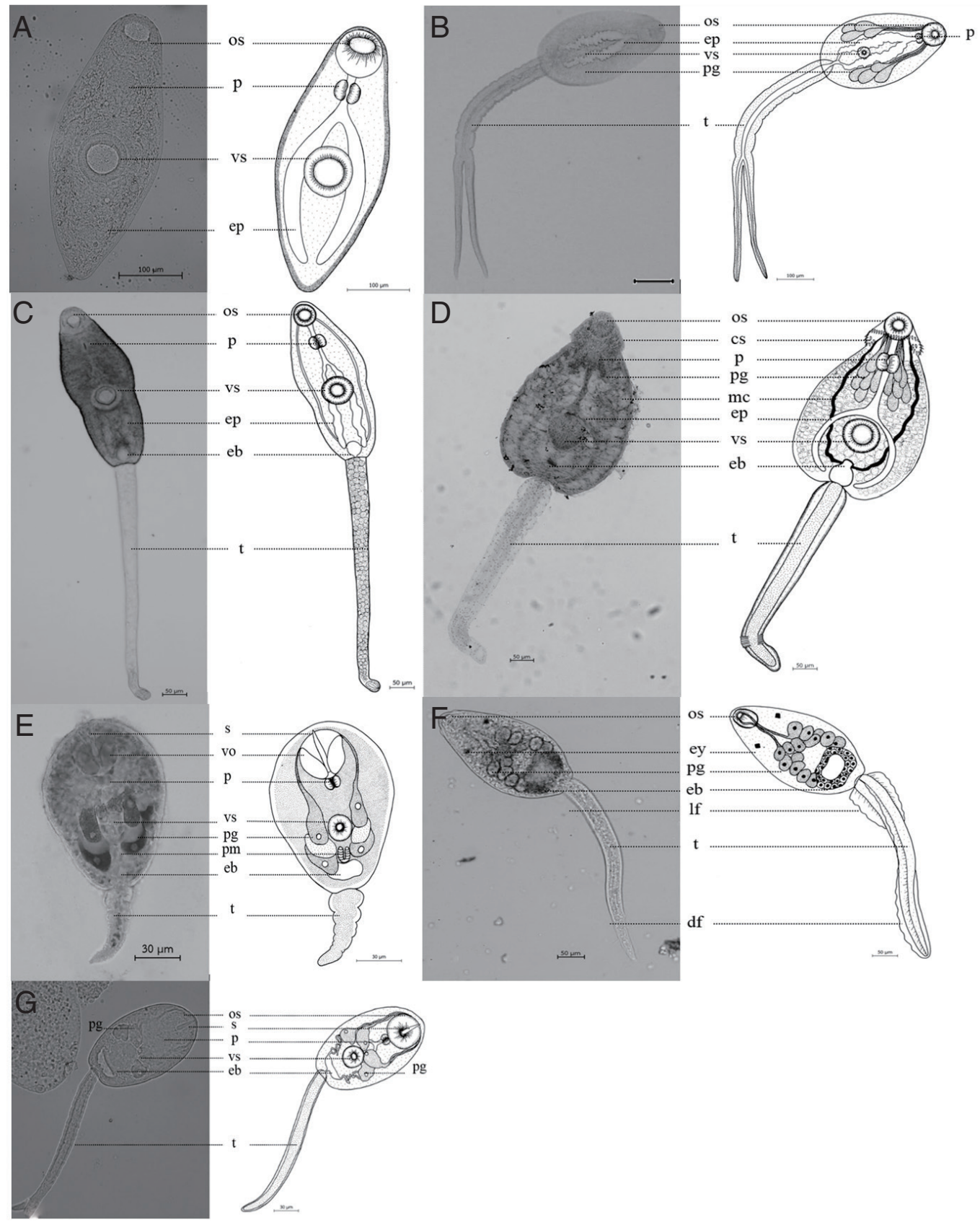

Fig. 4. Seven types of cercariae were found as follows: (A) Cercariae. (B) Furcocercous cercariae. (C) Megalurous cercariae. (D) Echinostome cercariae. (E) Virgulate cercariae. (F) Parapleurolophocercous cercariae. (G) Xiphidiocercariae. Abbreviations: cs, collar spine; eb, excretory bladder; ep, esophagus; ey, eye spot; If, lateral finfold; mc, main collecting tube; os, oral sucker; p, pharynx; pg, penetration gland; s, stylet; vo, virgulate organ; vs, ventral sucker; $t$, tail. 
cated that B. siamensis had the highest number of diverse cercarial types (7 types), followed by F. polygramma (3 types), $M$. tuberculata and F. martensi (2 types), and L. auricularia and I. exustus (1 type), respectively. Among the districts, Muang dis-

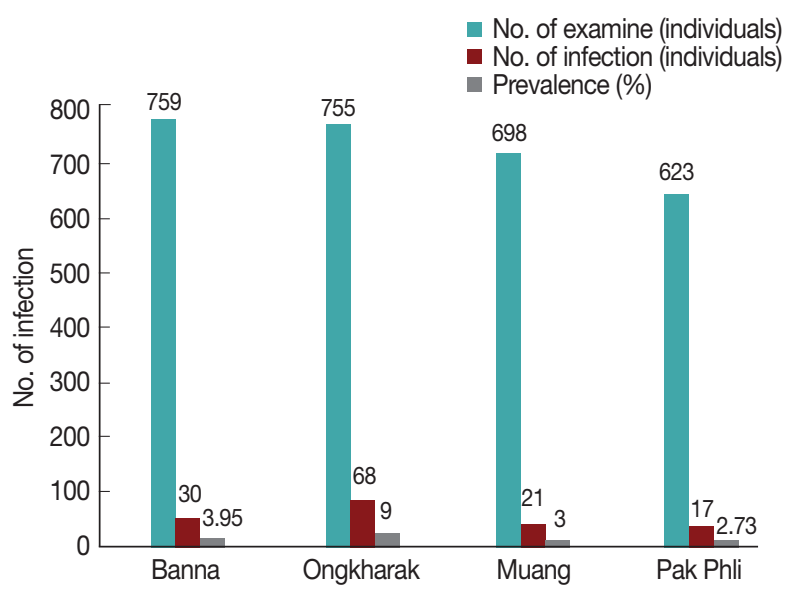

trict had the highest prevalence of cercarial infections (9.0\%) followed by Banna (4.0\%), Ongkharak (3.0\%), and Pak Phli district (2.7\%), respectively (Fig. 5).

A dendrogram was constructed for the ITS2 sequence data of the cercarial stage using the neighbor-joining (NJ) tree method with 10,000 replicates for the purpose of molecular identification. The dendrogram acquired from these results can be confirmed and separated into 6 clades, including Echinostomatida/Echinostomatidae (Echinostoma revolutum and Petasiger sp.), Echinostomatida/Philophthalmidae (Philophthalmus gralli), Opisthorchiida/Heterophyidae (Haplorchis taichui and Metagonimus hakubaensis), Plagiorchiida/Prosthogonimidae (Prosthogonimus cuneatus), Plagiorchiida/Lecithodendriidae (Ganeo trigrinus, Paralecithodendrium chilostomum, and Lecithodendrium sp.), and Strigeatida/Cyathocotylidae (Holostephanus dubinini), respectively (Fig. 6).

Fig. 5. The prevalence of cercarial infections in each district.

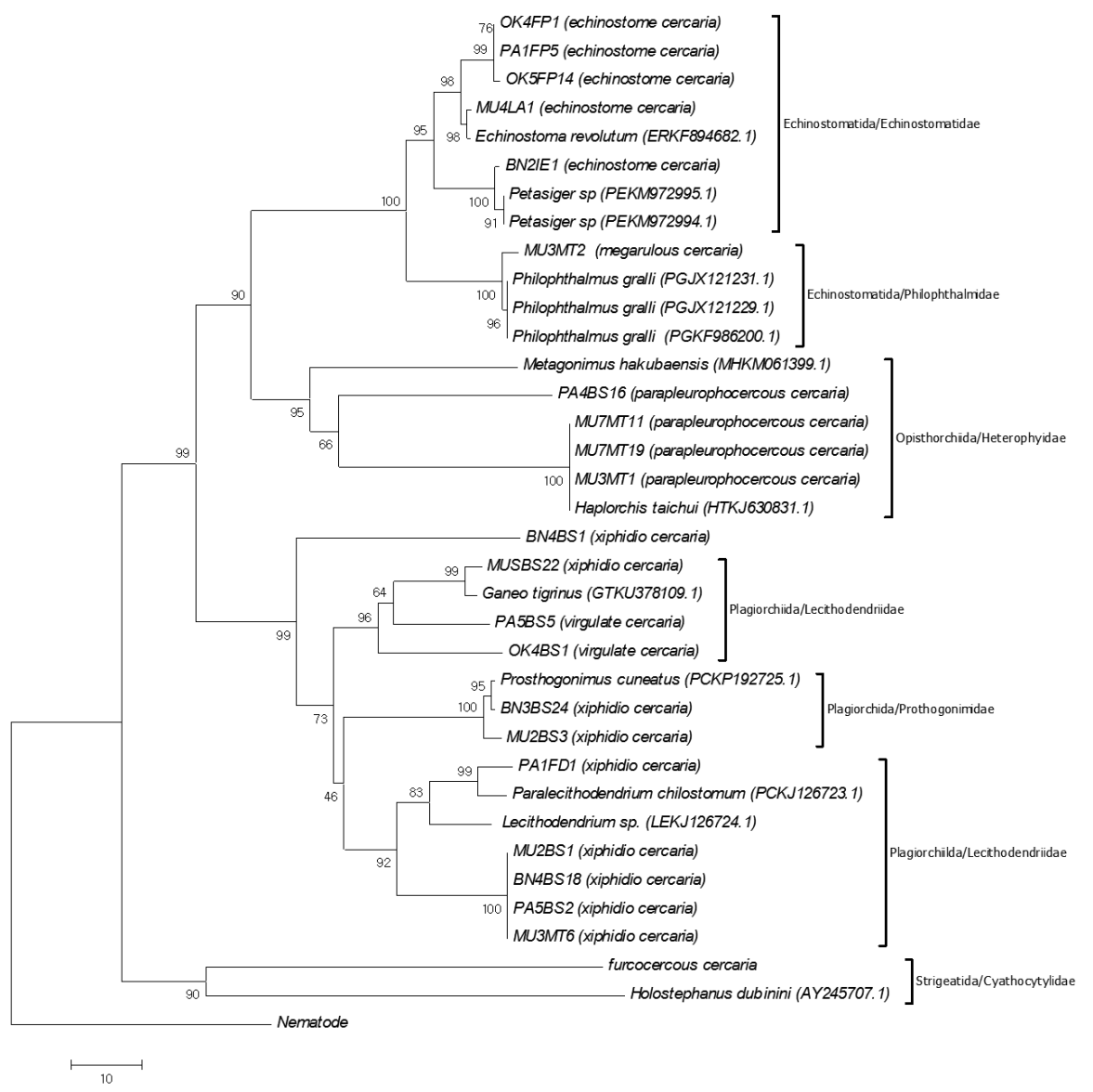

Fig. 6. The rooted phylogeny acquired from the partial ITS2 region of each cercarial type using the NJ method based on the Kimura 2-parameter model. Bootstrap values were computed independently for the purposes of 10,000 resembling. 


\section{DISCUSSION}

This study confirmed the existence of numerous freshwater snails in Nakhon Nayok province, Thailand that serve as the intermediate hosts of certain trematode species, such as B. siamensis, F. polygramma, I. exustus, L. auricularia, and M. tuberculata. A recent report, that examined parasitic infections among freshwater animals in 5 provinces of northern Thailand, reported finding of only 1 snail species (M. tuberculata) that serve as an intermediate host [9].

The thiarid snails displayed a high susceptibility for cercarial infections, which is in accordance with the previous report that had concluded that thiarid snails harbor the larvae of intestinal and blood flukes [29]. Furthermore, M. tuberculata and T. granifera (Thiaridae) are considered to be medically important because they can serve as the primary intermediate host for intestinal flukes [30]. Hence, these snail species were found to have infected with many species of trematodes that display a very low level of specificity and that are known to be susceptible to trematode infections.

Six species of snails, including B. Siamensis, F. polygramma, I. exustus, L. auricularia, and M. Tuberculate, were infected with cercariae with an overall prevalence of $4.7 \%$. The highest prevalence was recorded in Mueang district at $9.0 \%$. Due to the fact that this area is home to various water resources and ecosystems such as the Khundanprakanchon Dam along with various irrigation canals, paddy fields, and other such examples, this area can be considered a suitable environment for cercariae to be effectively transmitted to snails and then to fish, which can lead to the perpetuation of their life cycles. According to previous reports, it has been suggested that the prevalence value of trematode infections is increased when the study site is situated near a river or other freshwater source. The freshwater sources can sustain a high level of biodiversity, which can support the life cycle of the trematodes that are associated with humans and animals [31].

A total of 7 morphological cercarial types were found to have infected in snails acquired from Nakhon Nayok province. They were classified into several types based on their morphological differences according to Schell [3] (internal organ arrangement, place, number of suckers, and others).

Regarding molecular identification, several types of cercariae were analyzed in order to reconstruct the dendrogram. A relationship was shown among the 6 clades according to the specific type of cercariae; for example, the clade Echinostomatida/
Echinostomatidae group was found to be able to develop into the adult stage, which was in accordance with the findings of several previous reports $[4,11,32]$. The specimens of parapleurolophocercous cercariae in the clade can develop into intestinal trematodes in the family Heterophyidae, particularly $H$. taichui [8,33-36], megalurous cercariae can develop into avian eye trematode in the family Philopthalmidae [3], and furcocercous cercariae can develop into the family Cyathocotylidae [3]. Finally, xiphidiocercariae that were examined in this study developed into the family Lecithodendriidae, Prosthogonimidae, and Plagiorchiidae, namely, Prosthogonimus cuneatus, Ganeo trigrinus, Paralecithodendrium chilostomum, and Lecithodendrium sp. $[4,11]$. Previous studies have revealed that the metacercarial and adult stages of these trematode species were frequently found in second intermediate hosts and definitive hosts in Thailand [37-39].

In conclusion, freshwater snails have displayed a high level of importance with regard to the health of the public, as well as within the veterinary field. This study has contributed in the way of new and more accurate information on the trematode fauna that is present in Nakhon Nayok province, Thailand. The findings have served as an initial step for understanding the epidemiological situation and establishment of control program of trematode infections in humans and animals. This study also provided important information regarding how each cercarial type is developed into a specific trematode family or genus. Moreover, this study confirmed that the ITS2 data of the cercarial stage could be applied to investigate any potential phylogenetic relationships among different trematode species.

\section{ACKNOWLEDGMENTS}

We would like to thankfully acknowledge Srinakharinwirot University, Thailand for providing research fund and for granting us the use of many of the facilities. Finally, we would like to thank Dr. Russell Kirk Hollis for editing our manuscript.

\section{REFERENCES}

1. Roberts LS, Janovy J Jr, Gerald D. Foundations of Parasitology, 8th ed. New York, USA. McGraw-Hill. 2009.

2. Chontananarth T, Wongsawad C. Prevalence of Haplorchis taichui in field collected snails: a molecular approach. Korean J Parasitol 2010; 48: 343-346.

3. Schell SC. How to Know the Trematodes. Dubuque, Iowa, USA. W.C. Brown. 1970, pp 1-335. 
4. Chontananarth T, Wongsawad C. Epidemiology of cercarial stage of trematodes in freshwater snails from Chiang Mai province, Thailand. Asian Pac J Trop Biomed 2013; 3; 237-243.

5. Frandsen F, Christensen NO. An introductory guide to the identification of cercariae from African freshwater snails with special reference to cercariae of trematode species of medical and veterinary importance. Acta Trop 1984; 41: 181-202.

6. Wongsawad C, Kumchoo K. Studies on prevalence and intensity of Transversotrema patialensis (Trematoda: Transversotrematidae) in the snail intermediate host, Thiara scabra. J Med Appl Malacol 2000; 10: 37-40.

7. Ngern-klun R, Sukontason KL, Tesana S, Sripakdee D, Irvine KN, Sukontason K. Field investigation of Bithynia funiculata, intermediate host of Opisthorchis viverrini in northern Thailand. Southeast Asian J Trop Med Public Health 2006; 37: 662-672.

8. Dechruksa W, Krailas D, Ukong S, Inkapatanakul W, Koonchornboon T. Trematode infections of the freshwater snail family Thiaridae in the Khek river, Thailand. Southeast Asian J Trop Med Public Health 2007; 38: 1016-1028.

9. Mard-arhin N, Prawang T, Wongsawad C. Helminths of freshwater animals from five provinces in northern Thailand. Southeast Asian J Trop Med Public Health 2001; 32 (suppl): 206-209.

10. Krailas D, Chotesaengsri S, Dechruksa W, Namchote S, Chuanprasit C,Veeraveebsakij N, Boonmekam D, Koonchornboon T. Species diversity of aquatic mollusks and their cercarial infections; Khao Yai National Park, Thailand. J Trop Med Parasitol 2012; 35: 37-47.

11. Anucherngchai S, Tejangkura T, Chontananarth T. Epidemiological situation and molecular identification of cercarial stage in freshwater snails in Chao-Phraya basin, Central Thailand. Asian Pac J Trop Biomed 2016; 6: 539-545.

12. Pearson JC, Ow-Yang CK. New species of Haplorchis from Southeast Asia, together with Key to the Haplorchis-group of heterophyid trematode of the Region. Southeast Asian J Trop Med Public Health 1982; 13: 35-60.

13. Jousson O, Bartoli P, Pawlowski J. Molecular identification of developmental stages in Opecoelidae (Digenea). Int J Parasitol 1999; 29: 1853-1858.

14. Kaset C, Eursitthichai V, Vichasri-Grams S, Viyanant V, Grams R. Rapid identification of lymnaeid snails and their infection with Fasciola gigantica in Thailand. Exp Parasitol 2010; 126: 482-488.

15. Erensoy A, Kuk S, Ozden M. Genetic identification of Fasciola hepatica by ITS-2 sequence of nuclear ribosomal DNA in Turkey. Parasitol Res 2009; 105: 407-412.

16. Thaenkham U, Dekumyoy P, Komalamisra C, Sato M, Dung DT, Waikagul J. Systematics of the subfamily Haplorchiinae (Trematoda: Heterphyidae), based on nuclear ribosomal DNA genes and ITS2 region. Parasitol Int 2010; 59: 460-465.

17. Sripalwit $\mathrm{P}$, Wongsawad $\mathrm{C}$, Chontananarth $\mathrm{T}$, Anuntalabhochai S, Wongsawad P, Chai JY. Worm developmental and phylogenetic characteristic of Stellantchasmus falcatus (Trematoda: Heterophyidae) from Thailand. Korean J Parasitol 2015; 53: 201207.
18. Kong Q, Fan L, Zhang J, Akao N, Dong K, Lou D, Ding J, Tong Q, Zheng B, Chen R, Ohta N, Lu S. Molecular identification of Anisakis and Hysterothylacium larvae in marine fishes from the East China Sea and the Pacific Coast of central Japan. Int J Food Microbiol 2015; 199: 1-7.

19. Sato M, Thaenkham U, Dekumyoy P, Waikagul J. Discrimination of O. viverrini, C. sinensis, H. pumilio and H. taichui using nuclear DNA-based PCR targeting ribosomal DNA ITS regions. Acta Trop 2008; 109: 81-83.

20. Van Van K, Dalsgaard A, Blair D, Le TH. Haplorchis pumilio and $H$. taichui in Vietnam discriminated using ITS-2 DNA sequence data from adults and larvae. Exp Parasitol 2009; 123: 146-151.

21. Wongsawad C, Wongsawad P. Anuntalaphochai S, Chai JY, Sukontason K. Occurrence and molecular identification of liver and minute intestinal flukes metacercariae in freshwater fish from Fang-Mae Ai Agricultural Basin, Chiang Mai province, Thailand. Asian Biomed 2013; 7: 97-104.

22. Ghobadi H, Farahnak A. A faunistic survey on the cercariae of Bellamya (Viviparus) bengalensis snails and their zoonotic importance. Iran J Public Health 2004; 33: 38-42.

23. Loffy WM, Brant SV, Ashmawy KI, Devkota R, Mkoji GM, Loker ES. A molecular approach for identification of paramphistomes from Africa and Asia. Vet Parasitol 2010; 174: 234-240.

24. Brandt RAM. The non-marine aquatic mollusca of Thailand. Arch Moll Band 1974; 105: 1-423.

25. La Rue GR. The classification of digenetic trematode: a review and a new system. Exp Parasitol 1957; 6: 306-349.

26. Olsen OW. Animal Parasites: Their Life Cycles and Ecology. Baltimore, Maryland, USA. University Park. 1974, pp 1-565.

27. Ito J. Studies on Cercariae in Japan. Shizuoka, Japan. Shizuoka University. 1980, pp 516-538.

28. Barber KE, Mkoji GM, Loker ES. PCR-RFLP analysis of the ITS2 region to identify Schistosoma haematobium and S. bovis from Kenya. Am J Trop Med Hyg 2000; 2: 434-440.

29. Supian Z, Ikhwanuddin AM. Population dynamics of freshwater molluscs (Gastropod: Melanoides tuberculata) in Crocker Range Park, Sabah. Review of Biodiversity and Environmental Conservation (ARBEC) 2002; 1: 1-9.

30. Bogéa T, Cordeiro FM, Gouveia JS. Melanoides tuberculata (Gastropoda: Thiaridae) as intermediate host of Heterophyidae (Trematoda: Digenea) in Rio de Janeiro Metropolitan Area, Brazil. Rev Inst Med Trop S Paulo 2005; 47: 87-90.

31. Tum S, Puotinen ML, Copeman DB. A geographic information systems model for mapping risk of fasciolosis in cattle and buffaloes in Cambodia. Vet Parasitol 2004; 12: 141-149.

32. Fernández MV, Hamann MI, Ostrowski-de Núñez M. Echinostome cercariae from Biomphalaria straminea (Mollusca: Planorbidae) in a rice field from Northeastern Argentina. Rev Mex Biodivers 2014; 85: 1024-1031.

33. Umadevi K, Madhavi R. The life cycle of Haplorchis pumilio (Trematoda: Heterophyidae) from the Indian region. J Helminthol 2006; 80: 327-332.

34. Díaz MT, Hernandez LE, Bashirullah AK. Studies on the life cycle 
of Haplorchis pumilio (Looss, 1896) (Trematoda: Heterophyidae) in Venezuela. Rev Cientfica 2008; 18: 35-42.

35. Skov J, Kania PW, Dalsgaard A, Jørgensen TR, Buchmann K. Life cycle stages of heterophyid trematodes in Vietnamese freshwater fishes traced by molecular and morphometric methods. Vet Parasitol 2009; 160: 66-75.

36. Pinto HA, de Melo AL. Melanoides tuberculata (Mollusca: Thiaridae) as an intermediate host of Centrocestus formosanus (Trematoda: Heterophyidae) in Brazil. Rev Inst Med Trop Sap Paulo 2010; 52: 207-210.

37. Saijuntha W, Duenngai K, Tantrawatpan C. Zoonotic echino- stome infections in free-grazing ducks in Thailand. Korean J Parasitol 2013; 51: 663-667.

38. Krailas D, Veeravechsukij N, Chuanprasit C, Boonmekam D, Namchote S. Prevalence of fish-borne trematodes of the family Heterophyidae at Pasak Cholasid Reservoir, Thailand. Acta Trop 2016; 156: 79-86.

39. Nithikathkul C, Wongsawad C. Prevalence of Haplorchis taichui and Haplorchoides sp. metacercariae in freshwater fish from water reservoirs, Chiang Mai, Thailand. Korean J Parasitol 2008; 46: 109-112. 